\title{
SOIL PENETRATION RESISTANCE IN A RHODIC EUTRUDOX AFFECTED BY MACHINERY TRAFFIC AND SOIL WATER CONTENT
}

\author{
MOACIR T. DE MORAES ${ }^{1}$, HENRIQUE DEBIASI ${ }^{2}$, JULIO C. FRANCHINI ${ }^{2}$, \\ VANDERLEI R. DA SILVA ${ }^{3}$
}

\begin{abstract}
Soil compaction caused by machinery traffic reduces crop yields. This study aimed to evaluate the effects of intensive traffic, and the soil water content, on the soil penetration resistance (PR) of a Rhodic Eutrudox (Distroferric Red Latosol, Brazilian Classification), managed under no-tillage (NT). The experiment consisted of six treatments: NT with recent chiseling, NT without additional compaction, and NT with additional compaction by 4, 8, 10 and 20 passes of a harvester with a weight of $100 \mathrm{kN}$ (70 kN on the front axle). Undisturbed soil samples were collected at 5.5-10.5 cm and 13.5-18.5 cm depth to quantify the soil bulk density (BD). The PR was assessed in four periods, using an impact penetrometer, inserted in the soil to a depth of $46 \mathrm{~cm}$. The effect of traffic intensities on the PR was small when this variable was assessed with the soil in the plastic consistency. Differences in PR among treatments increased as the soil water content decreased. The increase in the values of $\mathrm{PR}$ and $\mathrm{BD}$ was higher in the first passes, but the increase in the number of traffics resulted in deeper soil compaction. The machinery traffic effects on PR are better characterized in the friable soil consistency.
\end{abstract}

KEYWORDS: soil layers with mechanical impedance, no-tillage, soil compaction, soil consistency, soil profile.

\section{RESISTÊNCIA DO SOLO À PENETRAÇÃO EM LATOSSOLO INFLUENCIADA PELO TRÁFEGO AGRÍCOLA E O CONTEÚDO DE ÁGUA DO SOLO}

RESUMO: A compactação do solo causada pelo tráfego de máquinas reduz a produtividade das culturas. O objetivo deste trabalho foi avaliar os efeitos do tráfego intensivo e do conteúdo de água do solo na resistência à penetração (PR) de um Latossolo Vermelho distroférrico, muito argiloso, manejado em sistema plantio direto (NT). O experimento foi composto por seis tratamentos: NT escarificado; NT sem compactação adicional; e NT com compactação adicional pelo tráfego de uma colhedora com massa de $100 \mathrm{kN}$ (70 kN no eixo dianteiro) por 4; 8; 10 e 20 passadas. A densidade do solo (BD) foi determinada utilizando amostras indeformadas, coletadas nas camadas de 5,5-10,5 cm e 13,5-18,5 cm. A RP foi determinada em quatro épocas, utilizando um penetrômetro de impacto, inserido no solo até a profundidade de $46 \mathrm{~cm}$. O efeito das intensidades de tráfego no NT sobre a PR foi pequeno quando esta variável foi avaliada com o solo na consistência plástica. As diferenças na PR entre os tratamentos aumentaram à medida que o conteúdo de água no momento da avaliação diminuiu. O aumento nos valores de PR e BD foi maior nas primeiras passadas, mas o incremento do número de tráfegos aumentou a profundidade de compactação do solo. O aumento da PR proporcionado pelo tráfego de máquinas é mais bem caracterizado quando determinado com o solo na consistência friável.

PALAVRAS-CHAVE: camadas de solo com impedimento mecânico, sistema plantio direto, compactação do solo, consistência do solo, perfil do solo.

\footnotetext{
${ }^{1}$ Doutorando do Programa de Pós-Graduação em Ciência do Solo da Universidade Federal do Rio Grande do Sul. Av. Bento Gonçalves, 7712, Prédio 41506, CEP 91540-000, Porto Alegre (RS). E-mail: moacir.tuzzin@gmail.com.

${ }^{2}$ Pesquisador A, Embrapa Soja. Rodovia Carlos João Strass, Distrito de Warta, Caixa Postal 231, CEP 86001-970, Londrina/PR. Email: henrique.debiasi@embrapa.br, julio.franchini@embrapa.br.

${ }^{3}$ Professor do Departamento de Ciências Agronômicas e Ambientais da Universidade Federal de Santa Maria, Campus de Frederico Westphalen - RS. CEP 98400-000 Frederico Westphalen (RS). E-mail: vanderlei@ufsm.br.

Recebido pelo Conselho Editorial em: 19-10-2012
}

Aprovado pelo Conselho Editorial em: 31-1-2013 


\section{INTRODUCTION}

The continuous traffic of heavy machinery on agricultural areas has led to soil structure degradation and crop yields reduction (ROQUE et al., 2011; BOTTA et al., 2010). The identification of the magnitude and depth of the soil compaction by traffic is important to scale the agricultural machinery weight, or indicate adequate management practices to increase the soil bearing capacity. However, few studies relating soil compaction to agricultural machinery traffic intensities have been carried out under Brazilian conditions (BERGAMIN et al., 2010).

Soil structure changes caused by inadequate soil management, animal trampling or machinery traffic have been evaluated applying several soil physical attributes. Soil bulk density (BD), pore size distribution and soil penetration resistance (PR) have been widely used as indicators of soil compaction. PR describes the mechanical resistance provided by the soil against something moving through it, e.g., roots or a tillage tool, showing high correlations with BD (CONTE et al., 2008; ROBOREDO et al., 2010; BENGOUGH et al., 2011; WHALLEY et al., 2007). VEIGA et al. (2007) found that PR is more sensitive to detect differences in the soil compaction level among soil management systems compared to determinations based on mass/volume ratios, being the physical property that best shows the machinery traffic effects on the soil structure (STRECK et al., 2004). The main factor controlling the crop growth is the soil water content, which determines the water availability to plants, aeration, temperature and PR (LETEY, 1985). These properties are also affected by BD and pore size distribution (COLLARES et al., 2011). According to the same authors, the PR is the main factor that influences the plant root growth. However, the definition of a critical PR value to root growth is difficult taking into account that crops respond differently to PR (REICHERT et al., 2007).

$\mathrm{PR}$ values increase exponentially as the soil water content decreases and the BD increases (VAZ et al., 2011). The rate of PR reduction with the increase in the soil water content is greater with higher BD values (TORRES \& SARAIVA, 1999). Therefore, compacted soil layers may not be detected if PR is assessed under high soil water contents (VAZ et al., 2011). Moreover, PR depends on other attributes such as the soil type (SILVA et al., 2009), organic matter content (TAVARES FILHO et al., 2012), soil texture (VAZ et al., 2011), soil compressibility (SILVA et al., 2002) and the metal-soil friction (DEXTER et al., 2007; SUN et al., 2012).

Several types of cone penetrometers can be utilized to evaluate PR, and the choice should be based on the soil compaction level. Manual static penetrometers provide field-level measurements of PR up to $5 \mathrm{MPa}$ (ASABE, 2010). Conversely, dynamic (impact) penetrometers enable PR measurements ranging from zero to $20 \mathrm{MPa}$ (VAZ et al., 2011). Additionally, the main advantages of using impact cone penetrometers are the low cost and the capacity to work in soils with stones and/or high resistance (low water content and high clay levels).

The objective of this study was to evaluate the effects of intensive traffic, and the soil water content, on the soil penetration resistance of a Rhodic Eutrudox, managed under no-tillage.

\section{MATERIALS AND METHODS}

The study was carried out at the experimental station of Embrapa Soja, located at an altitude of $620 \mathrm{~m}$, in Londrina $\left(23^{\circ} 11^{\prime} \mathrm{S}, 51^{\circ} 11^{\prime} \mathrm{W}\right)$, state of Paraná, southern Brazil. The trial was established on an Oxisol (Latossolo Vermelho Distroférrico, Brazilian classification; Rhodic Eutrudox, USA classification) managed under NT since 1996, with $731 \mathrm{~g}$ clay kg${ }^{-1}$ soil, $146 \mathrm{~g}$ silt $\mathrm{kg}^{-1}$ soil, $123 \mathrm{~g}$ sand $\mathrm{kg}^{-1}$ soil, $18.50 \mathrm{~g}$ organic carbon $\mathrm{kg}^{-1}$, and particle density of $2.96 \mathrm{Mg} \mathrm{m}^{-3}$ at 0 $20 \mathrm{~cm}$ depth. The average slope of the experimental area is $0.03 \mathrm{~m} \mathrm{~m}^{-1}$.

The experiment had a randomized block design with sampling in the plots and two replications. The treatments consisted of six compaction levels on 2,5 m wide and $20 \mathrm{~m}$ long plots: NT with recent chiseling (NTCh), NT without chiseling and without additional compaction (NT), and NT with additional compaction by harvester traffic in 4 different intensities, represented by four 
(NTC4), 8 (NTC8), 10 (NTC10) and 20 (NTC20) passes over the same track. The additional compaction was carried out on 08.16.2010 (month, day, year) by means of a self-propelled grain harvester (weight of $66 \mathrm{kN}$ ) equipped with grain header (weight of $12 \mathrm{kN}$ ) and with the grain tank filled (wheat, weight of $22 \mathrm{kN}$ ), presenting a total weight of $100 \mathrm{kN}$ (70 kN on the front axle). The harvester were equipped with single front tires, 18.4-30 R1, diagonals, inflated to pressure of 180 $\mathrm{kPa}$; and rear tires 9.00-16 F2 10PR, diagonals, inflated to a pressure of $410 \mathrm{kPa}$. The ground pressure of the front tires was estimated in $230 \mathrm{kPa}$, using a simple procedure proposed by O'SULLIVAN et al. (1999). Following this methodology, the soil-tire contact area was estimated from tire width and diameter, inflation pressure and load, using an empirical model developed for a rigid surface. The soil gravimetric water content (GWC) during the harvester traffic was equivalent to the field capacity $\left(0.34 \mathrm{~kg} \mathrm{~kg}^{-1}\right)$. The chiseling was performed seven days before the $1 \mathrm{st} P R$ evaluation, when the soil was in the friable consistency (GWC of $0.28 \mathrm{~kg} \mathrm{~kg}^{-1}$ ), by means of a chisel plow equipped with five shanks spaced $35 \mathrm{~cm}$ each other, and working at an average depth of 30 $\mathrm{cm}$, followed by a disking with a light disc harrow operating at $8 \mathrm{~cm}$ depth.

On 08/23/2010, the experiment was sprinkler-irrigated with $100 \mathrm{~mm}$ of water in order to uniform and increase the GWC up to the field capacity. The PR evaluations were carried out at four periods (2, 4, 11 and 23 days after irrigation), in layers of $2 \mathrm{~cm}$ to a depth of $46 \mathrm{~cm}$ using an impact penetrometer (IAA model/Planalsucar-Stolf) (STOLF, 1991) equipped with a $130 \mathrm{~mm}^{2}$ base area, $30^{\circ}$ stainless circular cone (ASABE, 2010). In each plot, the PR readings were performed at eight points spaced by $15 \mathrm{~cm}$ on a perpendicular line to the direction of the harvester or chisel plow pass, totalling 96 points per evaluation period. Two soil samples were collected in each plot and evaluation period at 0-10 $\mathrm{cm}$ and 10-20 cm depth to quantify the GWC (EMBRAPA, 1997).

Two days after the 4th PR evaluation, four trenches per treatment were opened and undisturbed soil samples were collected at depths of 5.5-10.5 and 13.5 to $18.5 \mathrm{~cm}$ using cores with an inner diameter of $5 \mathrm{~cm}$ and a height of $5 \mathrm{~cm}$. 6 cores were horizontally inserted into the wall of each trench and layer by means of a hydraulic jack, totalling 288 samples. The undisturbed soil samples were used to determine BD according to EMBRAPA (1997).

Statistical analyses were performed using the SAS LEARNING EDITION 8.0 (2002). The results of $\mathrm{BD}, \mathrm{GWC}$ and $\mathrm{PR}$ were subjected to variance analysis ( $F$ test, $\mathrm{p}<0.05$ ). The $\mathrm{BD}$ was analysed following a 6x2 factorial arrangement (compaction levels $\mathrm{x}$ depth). For GWC and PR, the statistical analysis was performed separately for each depth, following a 6x4 factorial arrangement (compaction levels $\mathrm{x}$ evaluation periods). Means were compared through the test, equivalent to Fisher's least significant difference test (LSD test) $(\mathrm{p}<0.05)$. The BD values were related to the traffic intensity by means of regression analysis ( $F$ test, $\mathrm{p}<0.05$ ).

\section{RESULTS AND DISCUSSION}

As expected, chiseling and traffic provided significant changes in soil structure, as evidenced by the BD values (Table 1). The lower BD values in both depths (5.5-10.5 and 13.5-18.5 cm) were obtained in the NTCh, demonstrating that chiseling is an effective practice to break compacted soil layers. Chiseling has been recommended to reduce the soil compaction level (KLEIN et al., 2009), increasing the optimal water range to plant growth by reducing the soil water content in which the PR reaches the critical values for root growth (CALONEGO \& ROSOLEM, 2011), as well as the number of days in which the soil moisture is adequate to plant growth (KAISER et al., 2009). Furthermore, chiseling has been found to increase the soil hydraulic conductivity and water infiltration rate (VIEIRA \& KLEIN, 2007). However, even one traffic with a light tractor after the chiseling can reduce drastically the effect of previous tillage on PR (VEIGA et al., 2007) leading to the soil recompaction in the short-term.

The BD increased exponentially with the increase of the harvester traffic intensity in both soil layers (Table 1 and Figure 1), but the effects were greater at 5.5-10.5 cm depth. BERGAMIN et al. (2010) also showed higher increases in the BD values due to the traffic of a tractor weighting $50 \mathrm{kN}$ 
in the topsoil $(10 \mathrm{~cm})$. The differences in the soil bearing capacity between the soil layers were likely small since the BD values were not influenced by the sampling depth (Table 1 and Figure 1). In addition, GWC values were also similar for both layers, since the traffic was performed in the field capacity. Thus, the greater BD values at 5.5-10.5 cm depth can be ascribed to the dissipation of the stress applied by the harvester wheels to the soil surface with increasing depth, which is explained mathematically by the Boussinesq equation (ALAKUKKU et al., 2003).

The greater changes in the soil compaction level were caused by the first harvester traffics, but increases in the BD were identified in both depths up to 20 passes (Table 1 and Figure 1). Higher increments in the soil compaction level during the first traffics of agricultural machinery were also observed by BERGAMIN et al. (2010). TOLON-BECERRA et al. (2010) reported that subsoil compaction depended on the axle load and the number of tractor passes. Interestingly, the average BD for NTC20 at 5.5-10.5 depth was $1.50 \mathrm{Mg} \mathrm{m}^{-3}$, which is similar to the maximum BD estimated by the Proctor test for this soil $\left(1.53 \mathrm{Mg} \mathrm{m}^{-3}\right.$ ) (TORRES \& SARAIVA, 1999).

TABLE 1. Descriptive statistics for the soil bulk density of a Rhodic Eutrudox under six compaction levels at 5.5-10.5 cm and 13.5-18.5 cm depth.

\begin{tabular}{|c|c|c|c|c|c|c|c|}
\hline Treatment $^{\mathrm{a}}$ & $\begin{array}{l}\text { Mini- } \\
\text { mum }\end{array}$ & $\begin{array}{l}\text { Maxi- } \\
\text { mum }\end{array}$ & Mean & Medium & Mode & $\begin{array}{l}\text { Standard } \\
\text { deviation }\end{array}$ & $\begin{array}{l}\text { Variation } \\
\text { Coefficient }\end{array}$ \\
\hline & \multicolumn{6}{|c|}{ 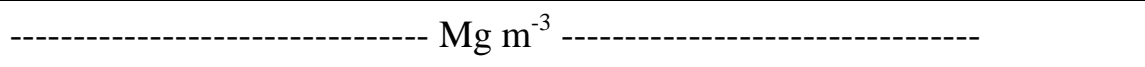 } & -- \% -- \\
\hline NTCh & 0.95 & 1.28 & $1.10 \mathrm{Ea} *$ & 1.11 & 1.04 & 0.073 & 6.67 \\
\hline NT & 1.16 & 1.32 & $1.25 \mathrm{Da}$ & 1.25 & 1.25 & 0.044 & 3.50 \\
\hline NTC4 & 1.28 & 1.46 & $1.36 \mathrm{Ca}$ & 1.36 & 1.36 & 0.038 & 2.84 \\
\hline NTC8 & 1.38 & 1.47 & 1.43Ba & 1.44 & 1.47 & 0.030 & 2.11 \\
\hline NTC10 & 1.36 & 1.52 & $1.45 \mathrm{Ba}$ & 1.46 & 1.46 & 0.040 & 2.86 \\
\hline NTC20 & 1.43 & 1.53 & $1.50 \mathrm{Aa}$ & 1.50 & 1.52 & 0.030 & 2.01 \\
\hline & & & - $13.5-18.5$ & | & ---- & ----------- & -- \\
\hline NTCh & 0.98 & 1.23 & $1.10 \mathrm{Ea}$ & 1.11 & 1.15 & 0.069 & 6.32 \\
\hline NT & 1.16 & 1.32 & $1.25 \mathrm{Da}$ & 1.26 & 1.27 & 0.043 & 3.42 \\
\hline NTC4 & 1.28 & 1.43 & $1.34 \mathrm{Cb}$ & 1.33 & 1.33 & 0.036 & 2.69 \\
\hline NTC8 & 1.29 & 1.42 & 1.36BCb & 1.36 & 1.35 & 0.026 & 1.93 \\
\hline NTC10 & 1.26 & 1.47 & $1.38 \mathrm{Bb}$ & 1.38 & 1.44 & 0.058 & 4.18 \\
\hline NTC20 & 1.34 & 1.49 & $1.42 \mathrm{Ab}$ & 1.42 & 1.43 & 0.048 & 3.42 \\
\hline
\end{tabular}

${ }^{a}$ No-tillage chiseled (NTCh); No-tillage without additional soil compaction (NT); No-tillage with additional compaction by 4 (NTC4), 8 (NTC8), 10 (NTC10) and 20 (NTC20) passes of a harvester.* Means followed by the same capital letter in the same layer and lowercase in layers of the same treatment did not differ among them by the LSD test at the $5 \%$ level of error probability.

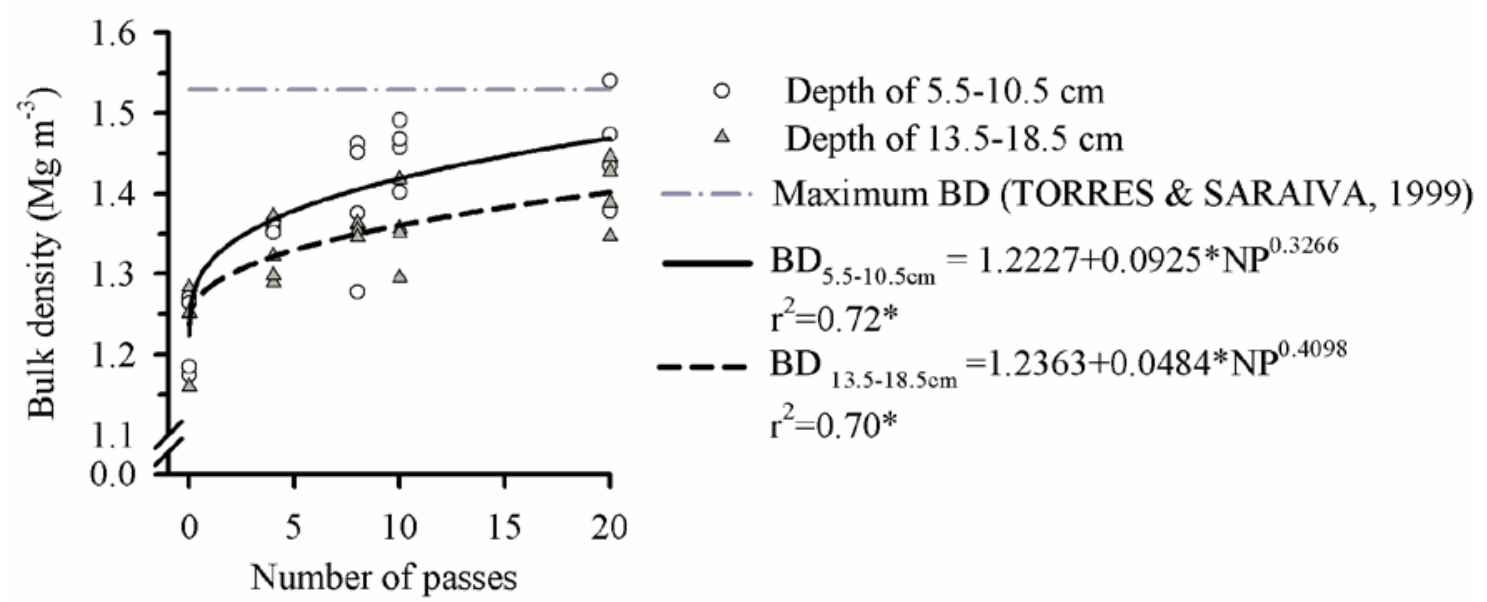

FIGURE 1. Soil bulk density (BD) at $5.5-10.5 \mathrm{~cm}$ and $13.5-18.5 \mathrm{~cm}$ depth as affected by the number of harvester passes on a Rhodic Eutrudox. *equations statistically significant (F test, $\mathrm{p}<0.05)$. 
For GWC at the moment of PR assessment, the interaction between compaction levels and evaluation periods was not significant $(\mathrm{p}<0.05)$, in both layers. The GWC decreased from the 1st to the 4th assessment period, and this reduction was higher at 0-10 $\mathrm{cm}$ depth (Table 2). The compaction levels also influenced the GWC. The largest GWC at 0-10 cm depth were obtained in the NTCh and NT, whereas the lowest values were observed for the treatments with additional compaction. A similar behaviour was found at 10-20 cm depth; however, the NTC4 and NTC8 did not differ from the NTCh and NT. Moreover, the NTCh and NT resulted in higher GWC than the NTC10 and NTC20 in both layers.

The PR readings at different times and the absence of rainfall and irrigation during the evaluation period provided a wide variation in the GWC values (Table 2), enabling the PR assessment under different soil consistencies. For this soil, liquid, friability, and contraction limits were estimated at $0.45,0.29$ e $0.25 \mathrm{~kg} \mathrm{~kg}^{-1}$, respectively (TORRES \& SARAIVA, 1999). Therefore, the PR was determined with the soil in the plastic (1st and 2nd evaluations), friable (3rd evaluation) and dry condition (4th evaluation).

The interaction between compaction levels and evaluation periods for the PR was significant in all depths $(\mathrm{p}<0.05)$. In general, the PR increased with the decrease in the GWC from the 1st to the 4th evaluation, and this increase was higher for the trafficked treatments in the topsoil $(0-15 \mathrm{~cm}$ depth) (Figure 2). The increase in the GWC reduces the internal friction and cohesive forces between the soil particles and aggregates leading to PR reduction (ASSIS et al., 2009; ROS et al., 2011). Moreover, the water acts as a lubricant, reducing the friction between the soil and the steel cone (CHANCELLOR, 1994). The PR values were significantly lower in the NTCh in comparison with other treatments at 0-30 cm depth regardless the evaluation time (Figure 2). Below $30 \mathrm{~cm}$ depth, the PR in NTCh was similar to NT, revealing that the soil disturbance by chisel shanks were limited to the $0-30 \mathrm{~cm}$ depth.

TABLE 2. Gravimetric soil water content as affected by evaluation times and compaction levels in a Rhodic Eutrudox.

\begin{tabular}{|c|c|c|c|c|c|}
\hline \multirow[b]{2}{*}{ Treatments $^{\mathrm{a}}$} & \multicolumn{4}{|c|}{ Assessment Periods } & \multirow[b]{2}{*}{ Means } \\
\hline & $\begin{array}{c}\text { First } \\
25 / 08\end{array}$ & $\begin{array}{c}\text { Second } \\
27 / 08\end{array}$ & $\begin{array}{l}\text { Third } \\
\text { 03/09 }\end{array}$ & $\begin{array}{c}\text { Fourth } \\
15 / 09\end{array}$ & \\
\hline & \multicolumn{5}{|c|}{ 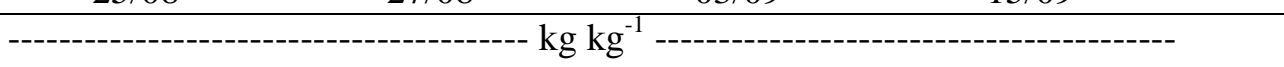 } \\
\hline NTCh & 0.34 & 0.32 & 0.29 & 0.25 & $0.30 \mathrm{a}$ \\
\hline NT & 0.33 & 0.32 & 0.27 & 0.24 & $0.29 \mathrm{ab}$ \\
\hline NTC4 & 0.32 & 0.31 & 0.24 & 0.22 & $0.28 \mathrm{bc}$ \\
\hline NTC8 & 0.32 & 0.30 & 0.25 & 0.23 & $0.28 \mathrm{bc}$ \\
\hline NTC10 & 0.32 & 0.30 & 0.27 & 0.22 & $0.27 \mathrm{c}$ \\
\hline NTC20 & 0.32 & 0.30 & 0.28 & 0.23 & $0.27 \mathrm{c}$ \\
\hline Means & $0.33 A^{*}$ & $0.31 \mathrm{~B}$ & $0.26 \mathrm{C}$ & $0.23 \mathrm{D}$ & \\
\hline CV (\%) & 2.10 & 3.23 & 7.67 & 4.29 & \\
\hline NTCh & 0.35 & 0.33 & 0.31 & 0.28 & $0.32 \mathrm{a}$ \\
\hline NT & 0.34 & 0.33 & 0.31 & 0.28 & $0.32 \mathrm{a}$ \\
\hline NTC4 & 0.33 & 0.33 & 0.29 & 0.27 & $0.31 \mathrm{ab}$ \\
\hline NTC8 & 0.33 & 0.33 & 0.30 & 0.27 & $0.31 \mathrm{ab}$ \\
\hline NTC10 & 0.33 & 0.33 & 0.29 & 0.25 & $0.29 \mathrm{~b}$ \\
\hline NTC20 & 0.33 & 0.33 & 0.29 & 0.26 & $0.30 \mathrm{~b}$ \\
\hline Means & $0.33 \mathrm{~A}$ & $0.33 \mathrm{~A}$ & $0.29 \mathrm{~B}$ & $0.27 \mathrm{C}$ & \\
\hline CV(\%) & 2.19 & 3.04 & 4.78 & 2.96 & \\
\hline
\end{tabular}

${ }^{a}$ No-tillage chiseled (NTCh); No-tillage without additional soil compaction (NT); No-tillage with additional compaction by 4 (NTC4), 8 (NTC8), 10 (NTC10) and 20 (NTC20) passes of a harvester. *At each depth, means followed by the same letter, capital in the line, and lowercase in the column, do not differ among them by the LSD test, at the level of 5\% of error probability. 
The traffic effects on the PR depended on the evaluation time and the number of passes (Figure 2). Trafficked treatments, even at higher intensities (NTC10 and NTC20), increased the PR in relation to the control without traffic (NT) only up to $12 \mathrm{~cm}$ depth in the 1st evaluation (Figure 2a), which was performed with the soil in the plastic consistency. In the 2nd evaluation (Figure 2b), the NTC4 resulted in higher PR than NT up to 10-12 cm depth, resembling the 1st assessment (Figure 2a). However, the increase in the number of passes (NTC8, NTC10 and NTC20) increased the PR in relation to NT up to $18 \mathrm{~cm}$ depth (Figure 2b), indicating that the reduction in GWC observed from the 1st to the 2nd evaluation resulted in a greater sensitivity of the PR to soil compaction caused by the harvester traffic. In general, considering the soil layers affected by the harvester traffic, the higher the number of passes, the higher the PR values in the 1st (Figure 2a) and 2nd (Figure 2b) evaluations.

Penetration resistance $(\mathrm{MPa})$
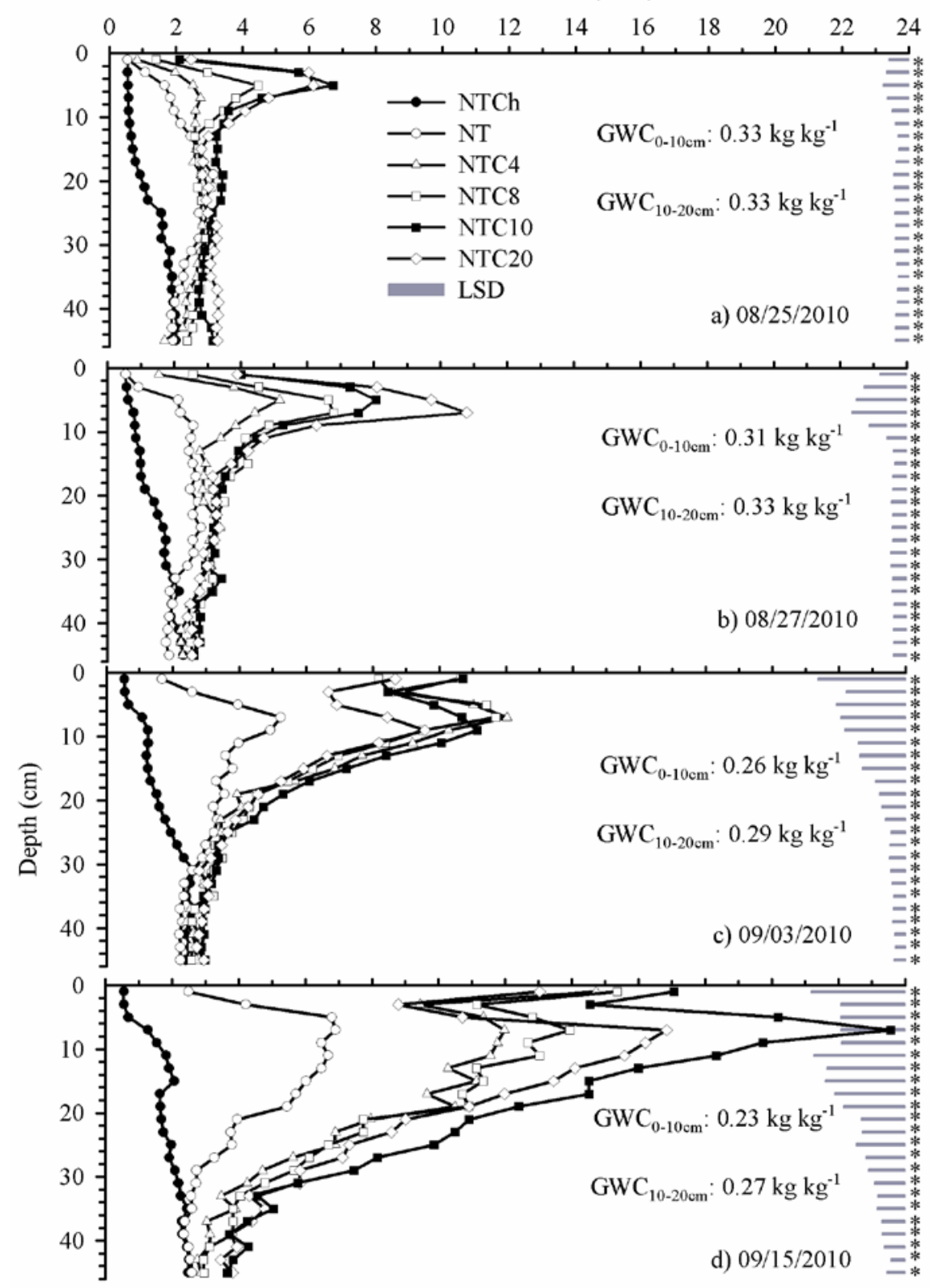

FIGURE 2. Penetration resistance of a Rhodic Eutrudox by layers of $2 \mathrm{~cm}$, at 0-46 cm depth, measured at 2 (a), 4 (b), 11 (c) and 15 (d) days after the irrigation, under six soil compaction levels [No-tillage chiseled (NTCh); No-tillage without additional soil compaction (NT); No-tillage with additional soil compaction by 4 (NTC4), 8 (NTC8), 10 (NTC10) and 20 (NTC20) harvester passes].* Horizontal lines indicate the least significant difference (LSD test, $\mathrm{p}<0.05$ ), and compare the means of treatments at each layer. 
In the 3rd (Figure 2c) and 4th (Figure 2d) PR evaluations, the depth of soil compaction by the harvester traffic increased compared to the previous evaluations (Figures 2a and 2b) for all trafficked treatments. When the soil was in the friable consistency (3rd evaluation), the NTC4 resulted in greater PR than the NT up to 16-18 cm depth, whereas the NTC8, NTC10, and NTC20 increased the PR in comparison to the NT up to $22 \mathrm{~cm}$ (Figure 2c). In the 4th evaluation (dry soil), the PR was higher in the NTC4 and NTC8 relative to NT up to $40 \mathrm{~cm}$ depth, but NTC10 and NTC20 increased the PR at least up to $46 \mathrm{~cm}$ depth (Figure 2d). Additionally, the PR differences between the trafficked treatments and the control (NT) in the 3rd and 4th evaluations were higher comparatively to the assessments conducted under higher GWC.

As previously observed for the 1st and 2nd evaluations, the PR also increased with the increment in the number of harvester passes in the 3rd and 4th assessments. Interestingly, the PR in NTC20 was equal or lower than in the other trafficked treatments in the last two evaluations (Figures 2c and 2d), even with the NTC20 showing higher BD values (Table 1). The high soil strength observed in the NTC20 under low soil water content led to the formation of vertical cracks below the cone during its displacement in the soil. These cracks facilitate the cone movement through the soil, reducing the PR to inconsistent values taking into account the high compaction level of the NTC20. MULQUEEN et al. (1977), and TO \& KAY (2005) reported reductions in the $\mathrm{PR}$ values due to small vertical cracks resulting from cone displacement through soils with high BD and low water content.

In general, the PR data (Figure 2) showed that the increase in the number of passes of a harvester with $70 \mathrm{kN}$ on the front axle resulted in the stress transmission to deeper soil layers. Similarly, SCHÄFFER et al. (2007) found that the stresses measured at $32 \mathrm{~cm}$ depth in the track centre increased from $80 \mathrm{kPa}$ in the 1st traffic to $120 \mathrm{kPa}$ in the 7th traffic of a grain harvester with a ground pressure of $120 \mathrm{kPa}$ and weight of $34 \mathrm{kN}$. The increasing depth of soil compaction with the increase in the tractor passes was also reported by TOLON-BECERRA et al. (2010), even using a tractor with a low axle load. Besides the passes number, the vertical stress distribution beneath wheels depends on the axle load and the ground pressure (LAMANDÉ \& SCHØNNING, 2011a), as well as soil characteristics such as the water content (LAMANDÉ \& SCHØNNING, 2011b) and structure (HAMZA \& ANDERSON, 2005).

The reduction in the GWC increased the PR sensitivity to detect soil compaction due to the harvester traffic (Figure 2), agreeing with the results reported by ASSIS et al. (2009). This result can be attributed to a higher increase in PR with the BD increase as the soil dries (MULQUEEN et al., 1977; TORRES \& SARAIVA, 1999; VAZ et al., 2011). As the soil becomes drier, compression under and around the probe becomes more important and the PR is very dependent on soil cohesion and BD (MULQUEEN et al., 1977). Under high GWC, these authors compare the soil with viscous materials, where the resisting force on a body moving through the material depends on the viscosity and not on the density. Furthermore, the reduction in the friction between the soil and the cone, resultant from the "lubricant action" of the water (CHANCELLOR, 1994), becomes more important as the soil compaction level increases.

Considering the PR sensitivity to soil compaction level, the dry soil condition (GWC lower than the soil contraction limit) would be the best option to PR evaluation. However, below a particular soil water potential, the PR values tend to decrease with the reduction in the GWC due to the decrease in the effective stress and the formation of cracks beneath the penetrometer cone (MULQUEEN et al., 1977; TO \& KAY, 2005), leading to the misinterpretation of PR values, as observed in this study (Figure 2d). Additionally, the soil strength is higher under lower GWC, making the PR evaluation difficult especially in compacted areas. Furthermore, when assessed in a dry soil condition, high PR values may reflect a high restriction to root growth by low soil water availability rather than a critical soil compaction level to root growth, as observed in the NT at 5-20 $\mathrm{cm}$ depth (Figure 2d). For this treatment and soil layer, the BD was less than $1.33 \mathrm{Mg} \mathrm{m}^{-3}$ (Table 1), considered the critical BD threshold to plant growth (TORRES \& SARAIVA, 1999). In spite of this, the PR was much higher than 3.5 MPa when evaluated under the dry soil condition (Figure 2d), 
value pointed out by TORRES \& SARAIVA (1999) as the critical PR threshold to root growth. Thus, as previously indicated by TORRES \& SARAIVA (1999) and ASSIS et al. (2009), the best soil water content to assess PR is the correspondent to the friable consistency, since this condition favours the detection of the traffic effects on the soil compaction level, and also enables an easy and precise determination of PR.

\section{CONCLUSIONS}

The soil penetration resistance increases with the number of traffics mainly after the first machinery passes.

The increase of soil penetration resistance in depth is determined by number of traffics.

The sensitivity of the soil penetration resistance decreases with the increase in the soil water content.

The machinery traffic effects on soil penetration resistance are better characterized in the friable soil consistency.

\section{ACKNOWLEDGMENTS}

To the employees of crop and soil management team of Embrapa Soja, Donizete Aparecido Loni, Mariluci da Silva Pires, Everson Balbino, Eliseu Custodio, João Ribeiro de Macedo, Agostinho Aparecido da Silva, Ildefonso Acosta Carvalho and Gustavo Garbelini, for the participation in conducting the experiment and data collection.

\section{REFERENCES}

ALAKUKKU, L.; WEISSKOPF, P.; CHAMEN, W.C.T.; TIJINK, F.G.J.; VAN DER LINDEN, J.P.; PIRES, S.; SOMMER, C.; SPOOR, G. Prevention strategies for field traffic-induced subsoil compaction: a review Part 1. Machine/soil interactions. Soil and Tillage Research, Amsterdam, v. 73, n. 1-2, p. 145-160, 2003.

ASABE STANDARDS. S313.3. Soil cone penetrometer. 57th St. Joseph: ASABE, 2010.

ASSIS, R.L.; LAZARINI, G.D.; LANÇAS, K.P.; CARGNELUTTI FILHO, A. Evaluation of soil resistance to penetration in different soils with varying moisture contents. Engenharia Agrícola, Jaboticabal, v.29, n.4, p. 558-568, 2009.

BENGOUGH, A.G.; McKENZIE, B. M.; HALLET, P. D.; VALENTINE, T. A. Root elongation, water stress, and mechanical impedance: a review of limiting stresses and beneficial root tip traits. Journal of Experimental Botany, Lancaster, v.62, n.1, p.59-68, 2011.

BERGAMIN, A.C.; VITORINO, A.C.T.; FRANCHINI, J.C.; SOUZA, C.M.A.; SOUZA, F.R. Induced compaction of a Rhodic Acrustox as related to maize root growth. Revista Brasileira de Ciência do Solo, Viçosa-MG, v.34, n.3, p.681-691, 2010

BOTTA, G.F.; TOLON-BECERRA, A.; LASTRA-BRAVO, X.; TOURN, M. Tillage and traffic effects (planters and tractors) on soil compaction and soybean (Glycine max L.) yields in Argentinean pampas. Soil and Tillage Research, Amsterdam, v.110, n.1, p.167-174, 2010.

CALONEGO, J.C.; ROSOLEM, C.A. Least limiting water range in soil under crop rotations and chiseling. Revista Brasileira de Ciência do Solo, Viçosa-MG, v.35, n.3, p.459-771, 2011.

CHANCELLOR, W. J. Soil physical properties. In: UPADHYAYA, S. K.; CHANCELLOR, W. J.; PERUMPRAL, J. V.; SCHAFER, R. L.; GILL, W. R.; VANDENBERG, G. E. (Ed.). Advances in soil dynamics. St. Joseph: American Society of Agricultural Engineers, 1994. p. 21-254 (ASAE monograph, 12). 
COLLARES, G.L.; REINERT, D.J.; REICHERT, J.M.; KAISER, D.R. Surface compaction of oxisols with crops-dairy cattle production in Northwest of Rio Grande do Sul, Brazil. Ciência Rural, Santa Maria, v.41, n.2, p.246-250, 2011

CONTE, O.; LEVIEN, R.; TREIN, C.R.; MAZURANA, M.; DEBIASI, H. Mechanical resistance of soil and traction force by planter chisel type openers in crop-livestock system. Engenharia Agrícola, Jaboticabal, v.28, n.4, p.730-739, 2008.

DEXTER, A.R.; CZYZ, E.A.; GAT, O.P. A method for prediction of soil penetration resistance. Soil and Tillage Research, Amsterdam, v.93, p.412-419, 2007.

EMBRAPA - Empresa Brasileira de Pesquisa Agropecuária. Manual de métodos de análise de solo. 2. ed. Rio de Janeiro, 1997. 212p.

HAMZA, M.A.; ANDERSON, W.K. Soil compaction in cropping systems: A review of the nature, causes and possible solutions. Soil and Tillage Research, Amsterdam, v. 82, n. 2, p.121-145, 2005.

KAISER, D.R.; REINERT, D.J.; REICHERT, J.M.; COLLARES, G.L.; KUNZ, M. Least limiting water range in an Oxisol profile penetrated by common bean roots under different compaction levels. Revista Brasileira de Ciência do Solo, Viçosa-MG, v.33, n.4, p.845-855, 2009.

KLEIN, V.A.; BASEGGIO, M.; MADALOSSO, T. Physical quality indicators in Latosol under no tillage chiseled. Ciência Rural, Santa Maria, v.39, n.9, p. 2475-2481, 2009.

LAMANDÉ, M.; SCHØNNING, P. Transmission of vertical stress in a real soil profile. Part II: Effect of tyre size, inflation pressure and wheel load. Soil and Tillage Research, Amsterdam,v.114, n.2, p.71-77, 2011a.

LAMANDÉ, M.; SCHØNNING, P. Transmission of vertical stress in a real soil profile Part III: Effect of soil water content. Soil and Tillage Research, Amsterdam, v.114, n.2, p.78-85, 2011 b.

LETEY, J. Relationship between soil physical properties and crop production. Advances in Soil Sciences, New York, v.1, n.1, p.277-293, 1985.

MULQUEEN, J.; STAFFORD, J. V.; TANNER, D. W. Evaluation of penetrometers for measuring soil strength. Journal of Terramechanics, Oxford, v.14, n.3, p. 137-151, 1977.

O’SULLIVAN, M.F.; HANSHALL, J. K.; DICKSON, J.W.A. A simplified method for estimating soil compaction. Soil and Tillage Research, Amsterdam, v. 49, n.4, p325-335, 1999.

REICHERT, J. M.; SUZUKI, L.E.A.S.; REINERT, D.J. Compactação do solo em sistemas agropecuários e florestais: Identificação, efeitos, limites críticos e mitigação. In: CERETTA, C. A.; SILVA, L. S.; REICHERT, J. M. (Ed.). Tópicos em Ciência do Solo, Viçosa: Sociedade Brasileira de Ciência do Solo, 2007. v.5, p.49-134.

ROBOREDO, D.; MAIA, J.C. S.; OLIVEIRA, O.J. ; ROQUE, C.G. The use of two penetrometers in the evaluation of soil strength in a Distrophic Red Latosol. Engenharia Agrícola, Jaboticabal, v.30, n.2, p. 308-314, 2010.

ROQUE, A.A.O.; SOUZA, Z.M.; ARAUJO, F.S.; SILVA, G.R.V. Soil physical attributes and least limiting water range of a Distrofic Red Latossol under agricultural traffic control. Ciência Rural, Santa Maria, v.41, n.9, p.1536-1542, 2011.

ROS, V.V.; SOUZA, C.M.A.; VITORINO, A.C.T.; RAFULL, L.Z.L. Oxisol resistence to penetration in no-till system after sowing. Engenharia Agrícola, Jaboticabal, v.31, n.6, p.11041114, 2011.

SAS LEARNING EDITION. Getting started with the SAS Learning Edition. Cary, 2002. 200p.

SCHÄFFER, B.; ATTINGER, W.; SCHULIN, R. Compaction of restored soil by heavy agricultural machinery - Soil physical and mechanical aspects. Soil and Tillage Research, Amsterdam, v.93, n.1, p.28-43, 2007. 
SILVA, V.R.; REICHERT, J.M.; REINERT, D.J.; BORTOLUZZI, E.C. Soil water dynamics related to the degree of compaction of two Brazilian Oxisols under no-tillage. Revista Brasileira de Ciência do Solo, Viçosa-MG, v.33, n.5, p.1097-1104, 2009.

SILVA, V.R.; REICHERT, J.M.; REINERT, D.J. SOARES, J.M. Factors controlling compressibility of a Paleudalf and a Haplortox soil. I - initial state of compactness. Revista Brasileira de Ciência do Solo, Viçosa-MG, v.26, n.1, p.1-8, 2002. (in Portuguese with English abstract).

STOLF, R., 1991. Theory and test of formulas for transforming impact penetrometer data in soil resistance. Revista Brasileira de Ciência do Solo, Viçosa-MG, v.15, n.2, p.229-235, 1991.

STRECK, C.A.; REINERT, D.J.; REICHERT, J.M.; KAISER, D.R. Soil physical alterations with soil compaction induced by traffic of a tractor in no-tillage system. Ciência Rural, Santa Maria, v.34, n.3, p.755-760, 2004.

SUN, Y.; MENG, F.; BUESCHER, W.; SCHULZE LAMMERS, P.; LIN, J.; ROSS, F.; MAACK, C.; CHENG, Q. A study to identify and correct friction-induced error of penetration measurement for agricultural materials. Measurement: Journal of the International Measurement Confederation. Amsterdam, v.45, n.5, p.829-835, 2012.

TAVARES FILHO, J.; FELTRAN, C.T.M.; OLIVEIRA, J.F.; ALMEIDA, E. Modelling of soil penetration resistance for an Oxisol under no-tillage. Revista Brasileira de Ciência do Solo, Viçosa-MG, v.36, n.1, p.89-95, 2012.

TO, J.; KAY, B.D. Variation in penetrometer resistance with soil properties: the contribution of effective stress and implications for pedotransfer functions. Geoderma, Amsterdam, v. 126, n. 3-4, p. 261-276, 2005.

TOLON BECERRA, A.; BOTTA, G.F.; LASTRA BRAVO, X.; TOURN, M.; BELLORA MELCON, F.; VÁSQUEZ, J.; RIVERO, D.; LINARES, P.; NARDON, G. Soil compaction distribution under tractor traffic in almond (Prunus amigdalus L.) orchard in Almería, España. Soil and Tillage Research, Amsterdam, v.107, n.1, p.49-56, 2010.

TORRES, E.; SARAIVA, O.F. Camadas de impedimento mecânico do solo em sistemas agrícolas com a soja. Londrina: Embrapa Soja, 1999. 58p. (Circular Técnica, 23).

VAZ, C.M.P.; MANIERI, J.M.; DE MARIA, I.C.; TULLER, M. Modeling and correction of soil penetration resistance for varying soil water content. Geoderma, Amsterdam, v.166, n.1, p.92-101, 2011.

VEIGA, M.; HORN, R.; REINERT, D.J.; REICHERT, J.M. Soil compressibility and penetrability of an Oxisol from southern Brazil, as affected by long-term tillage systems. Soil and Tillage Research, Amsterdam, v.92, n.1-2, p. 104-113, 2007.

WHALLEY, W.R.; TO, J.; KAY, B.D.; WHITMORE, A.P. Prediction of the penetrometer resistance of soils with models with few parameters, Geoderma, Amsterdam, v.137, n.3-4, p. 370377, 2007.

VIEIRA, M.L.; KLEIN, V.A. Hydro-physical properties of an Oxisol under different management systems. Revista Brasileira de Ciência do Solo, Viçosa-MG, v.31, n.6, p.1271-1280, 2007. (in Portuguese with English abstract). 